\title{
VACUUM DRYING OF RED CURRANT (RIBES RUBRUM L.): PHYSICAL AND CHEMICAL PROPERTIES AND KINETIC MODELING
}

\author{
Anita S. Vakula*, Mirna V. Drašković Berger, Tatjana N. Daničić, Aleksandra N. Tepić Horecki, \\ Branimir M. Pavlić, Marija R. Jokanović, Zdravko M. Šumić \\ University of Novi Sad, Faculty of Technology, 21000 Novi Sad, Bulevar cara Lazara 1, Serbia
}

\author{
${ }^{*}$ Corresponding author \\ Tel: +381214853695 \\ Email: anitavakula@gmail.com
}

\begin{abstract}
Red currants (Ribes rubrum L.) were dried by vacuum drying on different drying temperatures $\left(30,40,50,60\right.$ and $70{ }^{\circ} \mathrm{C}$ ) at constant pressure (20 mbar). The main goal of the research was to investigate changes of physical and chemical properties of red currants at different conditions of vacuum drying process. Moisture content, water activity, rehydration power, total color change, shear force and total monomeric anthocyanin compounds were used as the most suitable quality indicators of dried red currant. The lowest moisture content, total color change and the highest rehydration power were noticed in the red currant sample dried on $60{ }^{\circ} \mathrm{C}, 20 \mathrm{mbar}, 16 \mathrm{~h}$, while the lowest water activity, shear force and the highest content of total monomeric anthocyanins were observed in the sample dried on $40{ }^{\circ} \mathrm{C}, 20 \mathrm{mbar}, 40 \mathrm{~h}$. Five empirical models (Henderson-Pabis, modified Henderson-Pabis, simplified Fick's diffusion, Peleg's and two term) were used for description of vacuum drying process.
\end{abstract}

Key words: drying temperature, water activity, rehydration, color, shear force, total monomeric anthocyanins

\section{INTRODUCTION}

Currants (Ribes) are grown all over the world in cooler climate areas, where they have moderately conditions in terms of growing (Mikulic-Petkovsek et al., 2014). Red currants (Ribes rubrum L.) are widely recognized for their nutritional quality and potential health benefit since they are rich sources of phytochemicals such as phenolics, anthocyanins, organic acids and vitamins (Djordjević et al., 2010). These bioactive compounds contented in red currants possess antioxidant properties and ability of scavenging free radicals produced in the human body during life (Szymanowska et al., 2015). Red currants could be consumed fresh, dried, frozen, or processed into jams, juices, jellies and other similar food products and food ingredients
(Mattila et al., 2016). Drying process, which considers water evaporation from the raw material, is widespread used method in the fruit-processing industry. Different drying techniques influence differently on chemical and biological reactions and fruit nutrients preservation during drying as well as on important quality properties of dried product (Djordjević et al., 2010).

Fruit has been commonly dried by convective drying with the hot air. Nowadays, usage of vacuum during drying, showed significant advantages compared to convective drying. Vacuum drying presents a drying technique where moisture, initially contented in fresh fruit, could be evaporated at low temperatures due to vacuum 
application. This way, fruit preserves initial shape and heat-sensitive compounds are not significantly damaged (Barta et al., 2012).

The main goal of this research was to investigate physical and chemical properties (moisture content, water activity, rehydration power, total color change and total monomeric anthocyanins content) of vacuum dried red currant samples. Vacuum drying was performed at constant pressure of 20 mbar for each of the drying conditions, which included temperature of $30,40,50,60$ and $70{ }^{\circ} \mathrm{C}$ and drying time $52,40,28,16$ and $4 \mathrm{~h}$, respectively. Another goal of this research was application of five common empirical models for description of vacuum drying process.

\section{MATERIALS AND METHODS}

\section{Sample preparation}

Red currants (Ribes rubrum L.) were collected near the Kopaonik Mountain (Serbia). After purchase, samples were frozen and stored at $-20{ }^{\circ} \mathrm{C}$ until drying, in order to insure the initial properties of raw samples and prevent potential deteriorative processes in the samples during the experiment.

\section{Chemicals}

All chemicals and reagents were of analytical reagent grade.

\section{Drying procedure}

Vacuum drying process was described in detail by Šumić et al. (2013).

\section{Experimental design}

Six samples of red currants, one fresh and five vacuum dried samples obtained at different temperatures $(30,40,50,60$ and $70{ }^{\circ} \mathrm{C}$ ), were investigated in this research. Moisture content (MC), water activity $\left(a_{w}\right)$ and total monomeric anthocyanins content (TMAC) were investigated in fresh red currant samples. Beside these analyses, rehydration power (RP), total color change $(\triangle \mathrm{E})$ and shear force (SF) were investigated in dried samples. Conditions of vacuum drying and obtained results for dried samples are presented in Table 2.

\section{Analyses}

Description of performed analyses (moisture content, water activity, total color change, shear force (texture analysis) and total monomeric anthocyanin content) is shown in detail in Šumić et al. (2016).

Statistical analysis

All experiments were performed in triplicate for statistical purpose. Results were presented as mean value. All the data were analyzed by univariate analysis of variance (ANOVA, $p<0.05$ ) in order to differentiate the samples by using the Tukey's Multiple Comparison Test and an $\alpha=0.05$ criterion. Statistica 10.0 (StatSoft Inc., Tulsa, OK, USA) was used for the ANOVA.

\section{Mathematical modelling}

Mathematical modelling applied in this research is explained in detail in research by Tepić Horecki et al. (2018). For mathematical modelling of experimental data, five commonly known empirical models given in Table 1 were applied. Non-linear least square regression was applied in order to determine model parameters and coefficients of correlation $\left(R^{2}\right)$ by using Statistica 10.0 (StatSoft Inc., Tulsa, OK, USA). Additionally, average absolute relative deviation (AARD), root mean square error (RMSE) and reduced chi-square ( $\mathrm{X} 2)$ were used for determination of fitting quality. These parameters were calculated according to equations presented in research by Tepić Horecki et al. (2018). Calculated model parameters for each applied model were presented as mean value \pm standard deviation (SD) and they are compared using Statistica 10.0 (StatSoft Inc., Tulsa, OK, USA).

\section{RESULTS AND DISCUSSION}

\section{Physical and chemical properties}

\section{Moisture content}

Fresh red currants possess high moisture content and thus their shelf-life is significantly limited. Accordingly, low moisture content in dried currants is desirable (Vakula et al., 2015). Sample of fresh red current possess moisture content of $85.2 \%$, which is similar with the previous investigation of Vakula et al. (2015) where 
Table 1.

Empirical models used for mathematical description of red currant vacuum dying process

\begin{tabular}{|c|c|c|c|c|c|c|c|c|c|}
\hline \multicolumn{3}{|l|}{ Model } & \multicolumn{4}{|c|}{ Equation } & & & Reference \\
\hline \multicolumn{3}{|c|}{ Henderson-Pabis } & \multicolumn{4}{|c|}{$M C=a \cdot e^{-k t}$} & \multicolumn{3}{|c|}{ Henderson and Pabis (1961) } \\
\hline \multicolumn{3}{|c|}{$\begin{array}{l}\text { Modified Henderson- } \\
\text { Pabis }\end{array}$} & \multicolumn{4}{|c|}{$M C=a \cdot e^{-k t}+b \cdot e^{-g t}+c \cdot e^{-h t}$} & \multicolumn{3}{|c|}{ Karathanos (1999) } \\
\hline \multicolumn{3}{|c|}{$\begin{array}{l}\text { Simplified Fick's } \\
\text { diffusion }\end{array}$} & \multicolumn{4}{|c|}{$M C=a \cdot e^{\left(-c \frac{t}{L^{2}}\right)}$} & \multicolumn{3}{|c|}{ Diamante and Munro (1991) } \\
\hline \multicolumn{3}{|l|}{ Peleg } & \multicolumn{4}{|c|}{$M C=M C_{0}-\frac{t}{k_{1}+k_{2} t}$} & \multicolumn{3}{|c|}{ Mercali et al. (2010) } \\
\hline \multicolumn{3}{|c|}{ Two term } & \multicolumn{4}{|c|}{$M C=a \cdot e^{-k_{1} t}+b \cdot e^{-k_{2} t}$} & \multicolumn{3}{|c|}{ Henderson (1974) } \\
\hline \multicolumn{10}{|c|}{${ }^{*} M C$-moisture content (in time $t$ ); $M C_{0}$-initial moisture content (in time $t=0$ ) } \\
\hline \multicolumn{10}{|c|}{$\begin{array}{l}\text { Table } 2 . \\
\text { Vacuum drying conditions and obtained results of: moisture content }(M C) \text {; water activity }\left(a_{w}\right) \text {; } \\
\text { rehydration power }(R P) ; \text { total color change }(\Delta E) \text {; shear force }(S F) \text { and total monomeric anthocyanins } \\
\text { content (TMAC) of dried red currant }\end{array}$} \\
\hline Sample & $\begin{array}{c}\mathrm{T} \\
\left({ }^{\circ} \mathrm{C}\right)\end{array}$ & P (mbar) & $\begin{array}{l}t \\
(h)\end{array}$ & $\begin{array}{l}\text { MC } \\
(\%)\end{array}$ & $a_{w}$ & $\begin{array}{l}\mathrm{RP} \\
(\%)\end{array}$ & $\Delta \mathrm{E}$ & $\begin{array}{l}\text { SF } \\
(g)\end{array}$ & $\begin{array}{l}\text { TMAC } \\
(\mathbf{m g} \\
\text { CGE/100g } \\
\text { DW) }\end{array}$ \\
\hline 1 & 30 & 20 & 52 & $15.35^{\mathrm{a}}$ & $0.404^{\mathrm{a}}$ & $45.00^{b}$ & $17.82^{\mathrm{a}}$ & $1254.2^{\mathrm{ab}}$ & $90.19^{\text {ab }}$ \\
\hline 2 & 40 & 20 & 40 & $13.49^{\mathrm{b}}$ & $0.341^{\mathrm{d}}$ & $47.50^{\mathrm{b}}$ & $23.48^{\mathrm{a}}$ & $398.5^{\mathrm{b}}$ & $103.85^{\mathrm{a}}$ \\
\hline 3 & 50 & 20 & 28 & $12.91^{b}$ & $0.397^{\mathrm{b}}$ & $47.50^{\mathrm{b}}$ & $17.83^{\mathrm{a}}$ & $1331.9^{a}$ & $84.69^{b}$ \\
\hline 4 & 60 & 20 & 16 & $9.68^{\mathrm{c}}$ & $0.372^{\mathrm{c}}$ & $53.75^{\mathrm{a}}$ & $17.73^{\mathrm{a}}$ & $1045.7^{\mathrm{ab}}$ & $76.48^{\mathrm{b}}$ \\
\hline 5 & 70 & 20 & 4 & $14.29^{\mathrm{ab}}$ & $0.402^{\mathrm{a}}$ & $43.75^{\mathrm{b}}$ & $17.89^{\mathrm{a}}$ & $1142.4^{\mathrm{ab}}$ & $87.79^{\mathrm{ab}}$ \\
\hline
\end{tabular}

$\overline{a, b, c, d}$ Means in a column that do not share a letter are significantly different $(p<0.05)$

it is reported that initial moisture content of the fresh red currants was $85.0 \%$. Moisture content $(\mathrm{MC})$ in dried red currant varied between 9.68 and $15.35 \%$ (Table 2). The lowest $M C$ was obtained in sample $4\left(60{ }^{\circ} \mathrm{C}, 20 \mathrm{mbar}, 16 \mathrm{~h}\right)$, while significantly the highest $(p<0.05)$ MC $(15.35 \%)$ was observed in sample 1 (30 ${ }^{\circ} \mathrm{C}, 20$ mbar, $52 \mathrm{~h}$ ), which was expected due to lower drying temperature and longer drying time of this sample as compared to drying conditions of all other dried samples. These results are in accordance with the research of Reis (2014) where vacuum drying conditions were investigated for different types of fruit and vegetables. It was observed that for celery slices, mango pulp, pumpkin slabs, coconut press cake, carrot, onion, ginger and loquat fruit, the higher temperature during drying leads to higher degree of moisture diffusion and higher degree of drying, regardless of the applied pressure which was constant in most cases.

\section{Water activity}

Water activity $\left(a_{w}\right)$ is the main parameter of microbial stability of dried products. Microorganisms grow best between 0.98$0.99 \mathrm{a}_{\mathrm{w}}$ values and their growth is causing food spoilage. Most microorganisms stop their growing at $a_{w}$ values $<0.90$ and some fungi stop growing at $a_{w}$ values 0.62 (Šumić et al., 2016). Temperature of fresh and dried red currant samples during $a_{w}$ measuring was $21{ }^{\circ} \mathrm{C}$. Water activity of fresh red currants was 0.937 and $a_{w}$ values obtained for vacuum dried samples varied between 0.341 and 0.404 (Table 2). The lowest $a_{w}$ value was obtained in sample $2\left(40{ }^{\circ} \mathrm{C}, 20 \mathrm{mbar}, 40 \mathrm{~h}\right)$, while significantly the highest $(p<0.05) a_{w}$ value was observed in sample $1\left(30{ }^{\circ} \mathrm{C}, 20\right.$ mbar, $52 \mathrm{~h}$ ). 


\section{Rehydration power}

Rehydration power is very important characteristic, which contributes to higher quality of vacuum dried heat-sensitive products (Alibaş, 2012). Rehydration power $(\mathrm{RP})$ in dried red currant samples varied between 43.75 and $53.75 \%$ (Table 2). In the research of Šumić et al. (2016) the highest result of RP $(41.25 \%)$ in red currant samples was observed for sample dried at $63{ }^{\circ} \mathrm{C}, 180 \mathrm{mbar}$ and $12 \mathrm{~h}$. Since higher RP of dried sample is preferable, the sample with the best value of RP in this research was Sample $4\left(60{ }^{\circ} \mathrm{C}, 20\right.$ mbar, $16 \mathrm{~h}$ ), while in other vacuum dried samples significantly lower $(p<0.05)$ RP values were obtained. Such high RP in Sample 4 is in accordance with the obtained $M C$ results where the lowest $M C$ content was obtained in the same sample.

\section{Total color change $(\triangle E)$}

The color of the product is a synonym for the quality, which makes it an important quality indicator of foodstuff, and it also plays a prominent role in final selection and consumption (Nieto-Sandoval et al., 1999). Red color of currants origins primarily from plant pigments called anthocyanins (Kopjar and Piližota, 2009). These pigments are very unstable and the one of the main goals during the drying process is also to protect the destruction of these compounds and on that way to preserve the initial color of the product. Total color change $(\Delta \mathrm{E})$ in dried red currant samples was in range between 17.73 and 23.48 (Table 2), with no significant differences between analyzed samples $(p<0.05)$.

\section{Shear force}

Firmness is also very important characterristic of dried products that may be disrupted due to application of high temperatures during drying process. As in the case of $\Delta \mathrm{E}$, this also influence negatively on consumers acceptability. Regarding this, it is desirable that dried red currants are not too fragile and firm. Shear forces (SF) (Table 2) of vacuum dried red currants were in the range between 398.5 and $1331.9 \mathrm{~g}$, which fits with the results experimentally observed in vacuum dried red currants presented in the research by
Šumić et al. (2016) where SF varied between 78.22 and $3420.22 \mathrm{~g}$. The lowest firmness was observed in sample 2 (40 ${ }^{\circ} \mathrm{C}, 20 \mathrm{mbar}, 40 \mathrm{~h}$ ), which characterizes this sample as the best one in terms of firmness, since lower firmness of dried fruit is often desirable. These results indicate that drying conditions for this sample did not affect a lot on destruction of cell integrity and loss of firmness.

\section{Total monomeric anthocyanins (TMAC)}

Anthocyanins are flavonoids which belong to a group of plant pigments that are responsible for the characteristic red and dark purple color of currants (Cristina et al., 2013; Chiou et al., 2014). Additionally, anthocyanins are biologically active compounds which have positive effects on human health such as antioxidant anti-inflammatory, cardio protective, antitumor, antidiabetic and eye function properties (Szymanowska et al., 2015). Total monomeric anthocyanins content (TMAC) in fresh red currant sample was $13.43 \mathrm{mg}$ CGE $/ 100 \mathrm{~g} F W$. This result is lower than TMAC obtained in the research by Cristina et al. (2013) where mean value of anthocyanins detected in fresh red currant sample varied between 20.51 and 44.56 mg CGE/100g FW, but also higher compared to results presented by Pantelidis et al. (2007), where this value was in the range from 1.3 to $7.8 \mathrm{mg} \mathrm{CGE} / 100 \mathrm{~g} F W$. TMAC of vacuum dried samples varied between 76.48 and $103.85 \mathrm{mg} \mathrm{CGE} / 100 \mathrm{~g}$ DW (Table 2). These results are in accordance with results obtained by Mitic et al. (2011), where TMAC in dried red currants was in the range from 21.5 to 111.75 $\mathrm{mg}$ CGE/100 $\mathrm{g}$ DW. TMAC obtained in sample $2\left(40{ }^{\circ} \mathrm{C}, 20 \mathrm{mbar}, 40 \mathrm{~h}\right)$ was significantly higher $(p<0.05)$ compared to all other samples, while the lowest TMAC was obtained in sample $4\left(60^{\circ} \mathrm{C}, 20\right.$ mbar, $16 \mathrm{~h}$ ). This indicates that the combination of lower temperatures and longer time applied for drying influenced positively on preserving the initial TMAC of fresh red currant sample.

\section{Kinetic models of vacuum drying}

The weight of red currants during vacuum drying was measured at 10 min intervals. Based on this data, MC of sample on each 
drying point was calculated by using the MC of dried red currant, for each drying condition. Vacuum drying of each sample was continued until no mass change was detected (final MC in equilibrium). The results calculated for $M C$ in all vacuum dried samples were converted to dimensionless moisture $(\Phi)$ and fitted to the five models (Henderson-Pabis, Modified HendersonPabis, Simplified Fick's diffusion, Peleg and two term). Statistical results of applied models, coefficients related to particular model $\left(k_{1}, k_{2}, a, k, b, g, c, h, L\right)$, coefficient of determination $R^{2}$, average absolute relative deviation (AARD), root mean square error (RMSE) and reduced chi-square $\left(x^{2}\right)$ are presented in Table 3. The maximum value of $R^{2}$ and minimum values of AARD, RMSE and $x^{2}$ were taken as the main criterion for choosing the model which approximates best the experimental data obtained for red currant vacuum drying. Comparison of observed and actual values of two term model for sample 2 is presented in Figure 1. $R^{2}$, AARD, RMSE and $x^{2}$ values for models in all experiments varied between 0.8866 and $0.9921 ; 5.43$ and $36.20 ; 1.7819$ and $7.8373 ; 0.0065$ and 0.4125 , respectively. The highest mean value of $R^{2}(0.9692)$ and the lowest mean value of RMSE (3.5251) were obtained for two term model, while the lowest mean value of AARD (9.87) and $x^{2}(0.0594)$ were observed for Modified Henderson-Pabis and Peleg's model, respectively. Based on these results, Two term model was selected as the most suitable model for representing the red currant vacuum drying since the highest $R^{2}$ and the lowest RMSE were obtained for that model. Sample $2\left(40{ }^{\circ} \mathrm{C}, 20 \mathrm{mbar}, 40 \mathrm{~h}\right)$ was the sample with the highest $R^{2}(0.9921)$ and also the lowest RMSE (1.7819), while the Sample $1\left(30^{\circ} \mathrm{C}, 20 \mathrm{mbar}, 52 \mathrm{~h}\right)$ was the sample with the lowest AARD (5.43) and the lowest $x^{2}(0.0065)$. Toğrul and Pehlivan, (2003), Sacilik and Elicin, (2006) and Doymaz, (2008) suggest logarithmic model as the most suitable in terms of fruit drying, while Aregbesola et al., (2015) suggests two term and modified Henderson-Pabis models as the most appropriate for nuts and kernels drying.

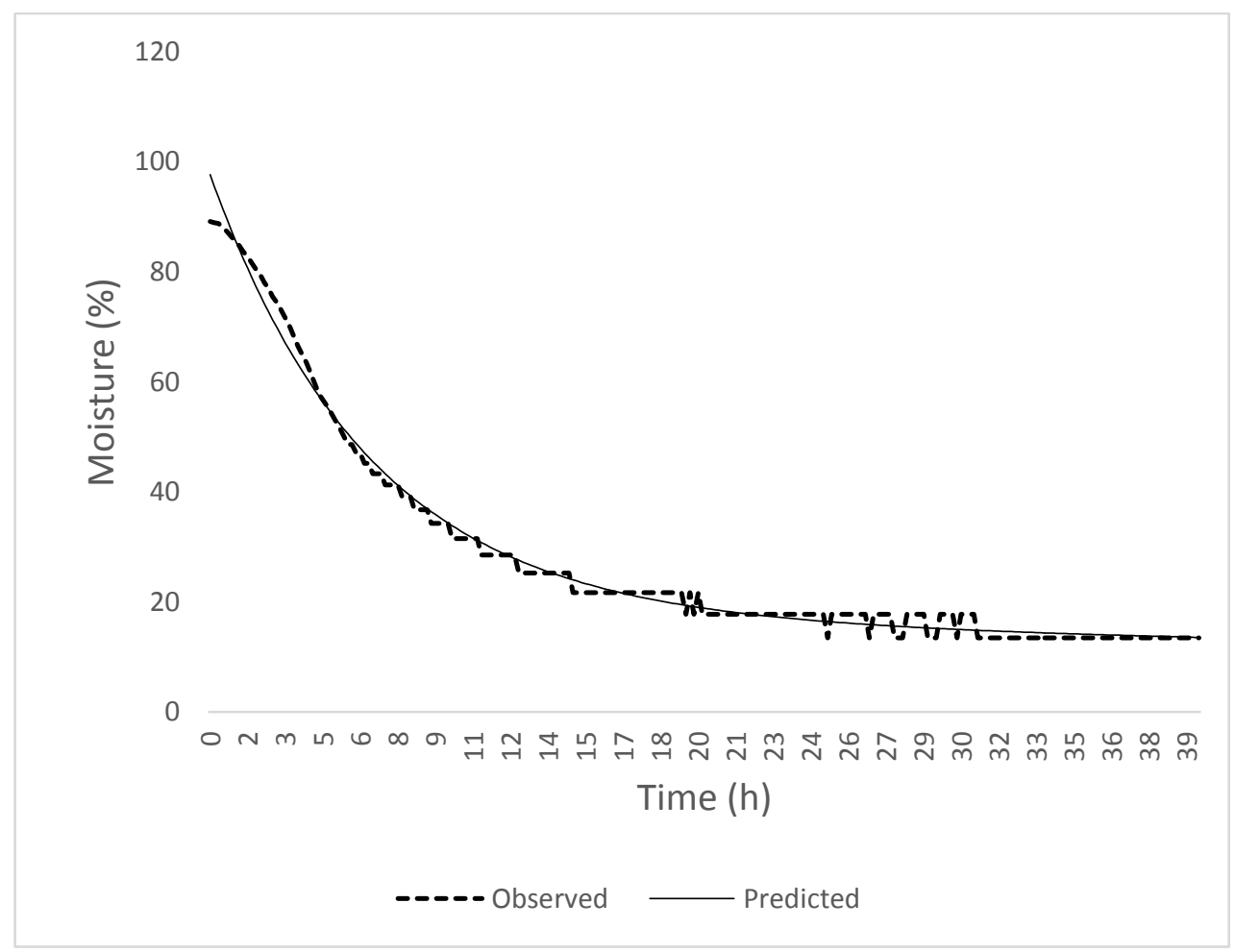

Figure 1. Observed and actual values of two-term model for sample 2 


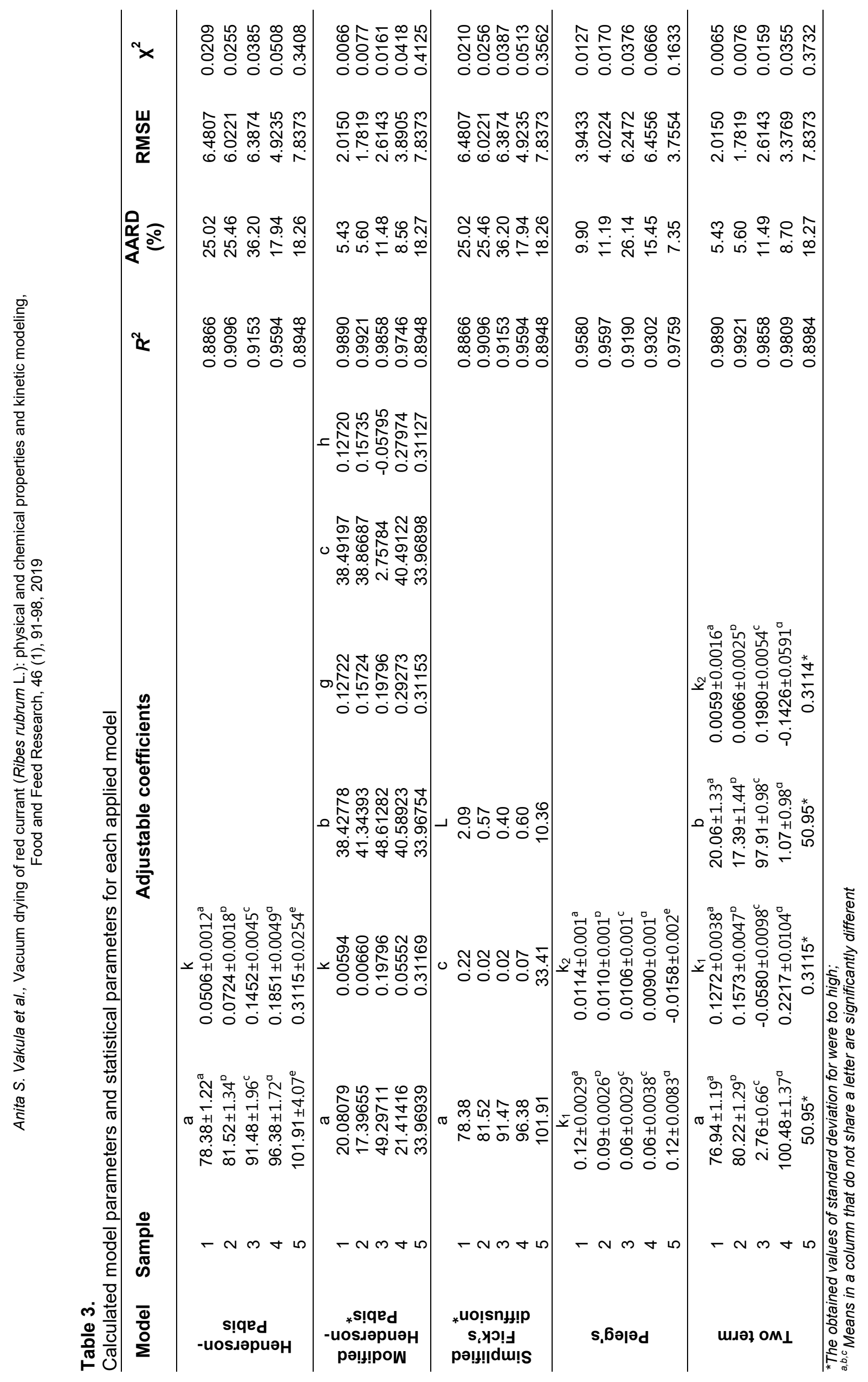




\section{CONCLUSIONS}

Based on the results obtained for the physical and chemical parameters of dried red currants it could be concluded that the moisture content in all dried red currant samples varied between 9.68 and $15.35 \%$, water activity between 0.341 and 0.404 , rehydration power between 43.75 and $53.75 \%$, total color change between 17.73 and 23.48, shear force between 398.5 and $1331.9 \mathrm{~g}$, and total monomeric anthocyanins content between 76.48 and 103.85 $\mathrm{mg}$ CGE/100g DW. The lowest moisture content $(9.68 \%)$, the lowest total color change (17.73) and the highest rehydration power $(53.75 \%)$ were noticed in sample $4\left(60^{\circ} \mathrm{C}, 20 \mathrm{mbar}, 16 \mathrm{~h}\right)$, while the lowest water activity (0.341), the lowest shear force $(398.5 \mathrm{~g})$ and the highest content of total monomeric anthocyanins content (103.85 mg CGE/100g DW) were obtained in sample $2\left(40{ }^{\circ} \mathrm{C}, 20\right.$ mbar, 40 h). After comparison of physical and chemical properties and drying conditions of these two dried red currant samples, it could be concluded that sample $4\left(60{ }^{\circ} \mathrm{C}\right.$, $20 \mathrm{mbar}, 16 \mathrm{~h}$ ) was the best in terms of quality indicators and economics of the process taking into account the significantly shorter drying time (16 h) compared to drying time of sample $2(40 \mathrm{~h})$. Thus, the conditions of drying the sample 4, i.e. $60^{\circ} \mathrm{C}, 20 \mathrm{mbar}, 16 \mathrm{~h}$ could be taken as optimal in terms of red currant vacuum drying investigated in this paper. The highest mean value of $R^{2}(0.9685)$ and the lowest mean value of RMSE (3.5251) was noticed for two term model. For this reason it was concluded that the two term model was selected as the most suitable for representing the red currant vacuum drying.

\section{ACKNOWLEDGMENTS}

The authors would like to thank the Ministry of Education, Science and Technological Development, Republic of Serbia, for financial support (Project No. TR 31044).

\section{REFERENCES}

1. Alibaş, İ. (2012). Determination of vacuum and air drying characteristics of celeriac slices. Jour- nal of Biological and Environmental Sciences, 6 (16), 1-13.

2. Barta, J., Balla, C., Vatai, G. (2012). Dehydration preservation of fruits. In Handbook of Fruits and Fruit Processing. Eds. N.K. Sinha, J.S. Sidhu, J. Barta, J.S.B. Wu, M.P. Cano, John Wiley and Sons, Ltd., pp. 133-151.

3. Chiou, A., Panagopoulou, E.A., Gatzali, F., De Marchi, S., Karathanos, V.T. (2014). Anthocyanins content and antioxidant capacity of Corinthian currants (Vitis vinifera L., var. Apyrena). Food Chemistry, 146, 157-165.

4. Cristina, P., Alina, I., Cristina, M. (2013). Production and quality potential of different black and red currant cultivars in Baneasa Research Station condition. Journal of Horticulture, Forestry and Biotechnology, 17 (4), 76-79.

5. Diamante, L.M., Munro, P.A. (1991). Mathematical modelling of hot air drying of sweet potato slices. International Journal of Food Science and Technology, 26 (1), 99-109.

6. Djordjević, B., Šavikin, K., Zdunić, G., Janković, T., Vulić, T., Oparnica, Č., Radivojević, D. (2010). Biochemical properties of red currant varieties in relation to storage. Plant Foods for Human Nutrition, 65 (4), 326-332.

7. Henderson, S.M. (1974). Progress in developing the thin layer drying equation. Transactions of the ASAE, 17 (6), 1167-1168.

8. Henderson, S.M., Pabis, S. (1961). Grain drying theory. II. Temperature effects on drying coefficients. Journal of Agricultural Engineering $R e$ search, 6, 169-174.

9. Karathanos, V.T. (1999). Determination of water content of dried fruits by drying kinetics. Journal of Food Engineering, 39 (4), 337-344.

10. Kopjar, M., Piližota, V. (2009). Copigmentation effect of phenolic compounds on red currant juice anthocyanins during storage. Croatian Journal of Food Science and Technology, 1 (2), 16-20.

11. Mattila, P.H., Hellström, J., Karhu, S., Pihlava, J. M., Veteläinen, M. (2016). High variability in flavonoid contents and composition between different North-European currant (Ribes spp.) varieties. Food Chemistry, 204, 14-20.

12. Mercali, G.D., Tessaro, I.C., Noreña, C.P., Marczak, L.D. (2010). Mass transfer kinetics during osmotic dehydration of bananas (Musa sapientum, shum.). International Journal of Food Science and Technology, 45 (11), 2281-2289.

13. Mikulic-Petkovsek, M., Schmitzer, V., Slatnar, A., Todorovic, B., Veberic, R., Stampar, F., Ivancic, A. (2014). Investigation of anthocyanin profile of four elderberry species and interspecific hybrids. Journal of Agricultural and Food Fhemistry, 62 (24), 5573-5580.

14. Mitić, M., Obradović, M., Kostić, D., Micić, R., Paunović, D. (2011). Phenolic profile and antioxidant capacities of dried red currant from Serbia, extracted with different solvent. Food Science Biotechnology, 20 (6), 1625-1631.

15. Nieto-Sandoval, J.M., Fernández-López, J.A., Almela, L., Muñoz, J.A. (1999). Dependence bet-ween apparent color and extractable color in paprika. Color Research and Application, 24 (2), 93-97. 
16. Pantelidis, G.E., Vasilakakis, M., Manganaris, G.A., Diamantidis, Gr. (2007). Antioxidant capacity, phenol, anthocyanin and ascorbic acid contents in raspberries, blackberries, red currants, gooseberries and Cornelian cherries. Food Chemistry, 102, 777-783.

17. Reis, F.R. (2014). Studies on conventional vacuum drying of foods. In Vacuum drying for extending food shelf-life. Ed. F.R. Reis, Springer Nature, Switzerland AG, pp. 7-18.

18. Šumić, Z., Tepić, A., Vidović, S., Jokić, S., Malbaša, R. (2013). Optimization of frozen sour cherries vacuum drying process. Food Chemistry, $136(1), 55-63$.

19. Šumić, Z., Vakula, A., Tepić, A., Čakarević, J., Vitas, J., Pavlić, B. (2016). Modeling and optimization of red currants vacuum drying process by response surface methodology (RSM). Food Chemistry, 203, 465-475.

20. Šumić, Z., Tepić, A., Jokić, S., Malbaša, R.
(2015). Optimization of frozen wild blueberry vacuum drying process. Hemijska Industrija, 69, 77-84.

21. Szymanowska, U., Złotek, U., Karaś, M., Baraniak, B. (2015). Anti-inflammatory and antioxidative activity of anthocyanins from purple basil leaves induced by selected abiotic elicitors. Food Chemistry, 172, 71-77.

22. Tepić Horecki, A., Vakula, A., Pavlić, B., Jokanović, M., Malbaša, R., Vitas, J., Jaćimović, V., Šumić, Z. (2018). Comparative drying of cornelian cherries: Kinetics modeling and physicochemical properties. Journal of Food Processing and Preservation, 42 (3), e13562.

23. Vakula, A., Radojčin, M., Pavkov, I., Stamenković, Z., Horecki-Tepić, A., Šumić, Z., Pavlić, B. (2015). The impact of different drying methods on quality indicators of red currants (Ribes rubrum L.). Journal on Processing and Energy in Agriculture, 19 (5), 249-254.

\title{
ВАКУУМ СУШЕЊЕ ЦРВЕНЕ РИБИЗЛЕ (RIBES RUBRUM L.): ФИЗИЧКО- ХЕМИЈСКЕ ОСОБИНЕ И МОДЕЛОВАЊЕ ПРОЦЕСА СУШЕЊА
}

\author{
Анита С. Вакула*, Мирна В. Драшковић Бергер, Татјана Н. Даничић, Алексанра Н. Тепић \\ Хорецки, Бранимир М. Павлић, Марија Р. Јокановић, Здравко М. Шумић \\ Универзитет у Новом Саду, Технолошки фракултет, 21000 Нови Сад, Булевар цара Лазара 1, \\ Србија
}

Сажетак: Црвене рибизле (Ribes rubrum L.) осушене су вакуум сушењем на различитим температурама сушења $\left(30,40,50,60\right.$ и $\left.70{ }^{\circ} \mathrm{C}\right)$ и на истом притиску (20 mbar). Циљ овог истраживања био је анализирање фризичко-хемијских особина црвене рибизле осушене у вакууму. Квалитет осушених узорака је оцењен на основу: садржаја влаге, активности воде, способности рехидрације, укупне промене боје, текстуре и садржаја укупних мономерних антоцијана. Најнижи садржај влаге, укупне промене боје и највећа моћ рехидратације забележени су у узорку црвене рибизле осушеном на $60{ }^{\circ} \mathrm{C}, 20 \mathrm{mbar}, 16 \mathrm{~h}$, док је најнижи садржај активности воде, најмања вредност силе пресецања и највећи садржај укупних мономерних антоцијана измерен у узорку осушеном на $40{ }^{\circ} \mathrm{C}, 20 \mathrm{mbar}, 40 \mathrm{~h}$. За апроксимацију експерименталних података вакуум сушења црвене рибизле употребљено је 5 математичких модела (Henderson-Pabis, modified Henderson-Pabis, simplified Fick's diffusion, Peleg и two-term).

Кључне речи: температура сушења, активност воде, способност рехидратације, сила пресецања, укупни мономерни антоцијани

Received: 16 January 2019

Received in revised form: 29 April 2019

Accepted: 14 May 2019 